Sexual Selections 
This page intentionally left blank 


\section{MARLENE ZUK}

\section{Sexual Selections}

What We Can and Can't Learn about Sex from Animals 
University of California Press

Berkeley and Los Angeles, California

University of California Press, Ltd.

London, England

(C) 2002 by the Regents of the University of California

Library of Congress Cataloging-in-Publication Data

\section{Zuk, M. (Marlene)}

Sexual selections : what we can and can't learn about sex from animals / Marlene Zuk.

p. $\mathrm{cm}$

Includes bibliographical references (p. ) and index.

ISBN o-520-21974-O (cloth : alk. paper)

I. Sexual behavior in animals. I. Title.

\section{QL76I.Z85 2002}

$591.56 ' 2-\mathrm{dc} 2 \mathrm{I}$

2001005771

Manufactured in the United States of America

$\begin{array}{lllllllll}\text { I0 } & 09 & 08 & 07 & 06 & 05 & 04 & 03 & 02\end{array}$

$\begin{array}{llllllllll}\text { IO } & 9 & 8 & 7 & 6 & 5 & 4 & 3 & 2 & \text { I }\end{array}$

The paper used in this publication is both acid-free and totally chlorine-free (TCF). It meets the minimum requirements of ANSI/NISO Z39.48-1992 (R 1997)

(Permanence of Paper). 